\title{
Potential for Use of Foreign Experience in Evaluation of Strategic Sustainability of Enterprises Relating to Transition of Russia's Economy to Strategic Path of Development
}

\author{
Galina P. Dovlatyan $^{1}$, Elena I. Makeeva ${ }^{1}$, Natalia T. Oboymova ${ }^{2} \&$ Elvira Y. Cherkesova $^{1}$ \\ ${ }^{1}$ Shakhty Institute (branch) of South Russian State Technical University, Shakhty, The Russian Federation \\ ${ }^{2}$ Institute of service and enterprise (branch) of Don State Technical University, Shakhty, The Russian Federation \\ Correspondence: Natalia T. Oboymova, Institute of service and enterprise (branch) of Don State Technical \\ University, 147, Shevchenko Str., Shakhty, Rostov Region, 346500, The Russian Federation. Tel: \\ 7-928-900-3015. E-mail: natascha73@mail.ru
}

\author{
Received: January 15, 2015 Accepted: March 2, 2015 Online Published: June 13, 2015 \\ doi:10.5539/ass.v11n20p56 URL: http://dx.doi.org/10.5539/ass.v11n20p56
}

\begin{abstract}
In this article, foreign experience of the rivals is studied, modern condition of national economy and strategic priorities of Russian producers are considered, which is a necessary step for internal and external development of industrial market. Russia's economy, possessing a substantial part of global resources, unfortunately, has a limited number of perspective sectors and occupies a low-profile place in the global distribution of labor. The authors researched the world experience in the increase of sustainable and strategic development of industrial enterprises in the context of its adaptation to Russia's conditions.

The authors present their evaluation of strategic sustainability of industrial enterprises of Rostov Oblast in the industrial landscape of Russia and reveal the strategic priorities of corporate planning, as a vector of perfecting institutional instruments for ensuring strategic sustainability of industry in Rostov Oblast.
\end{abstract}

Keywords: regional economy, strategic development of a sector, enterprises, foreign experience

\section{Introduction}

In modern competitive conditions, industrial enterprises require modernization: it's necessary to create innovational conditions for perspective development of Russia's economy and its entry to a new stage of development. It is impossible to reach this without activation of innovational processes of industrial enterprises, which acquires an important meaning for sustainable development of industrial sector. The existing "fall spots" reflect the slowdown of innovational and logical processes of Russia's industrial enterprises and are caused by the fact that industrial processes often feature low-end and aged technologies and innovations, and investment and financial support of their acquisition is rather low. A substantial technical and technological underrun of Russian enterprises of industrial complex from foreign rivals is still observed.

\section{Methods and Materials}

The authors used general scientific methods of statistical and systemic and functional approach and generalization, analysis and synthesis, as well as private methods of economic analysis - grouping, qualitative and quantitative analysis, expert evaluation, economic and mathematical analysis.

General theoretical issues of studying competitive development are viewed in the works of Gamble P., Cotler F., Merlene P., Porter M., Tailor S., Hayek F.

Scientific analysis of institutional economy and institutional approaches to development of various institutions is reflected in the works of Veblen T., Lakatos I., Nort D., Hodgons J.

Research on strategic management of industrial enterprises are reflected in the scientific works of Russian scientists: Andreev A, Vesnin V., Husyev Y., Egorov D., Ivanov E., Kuznetsov E., Nerovnya T., Ragimov F., Fatkhutdinov R., Faskhiev K.

It should be noted that among the scientists that try to find a scientific answer to real challenges of modernization of Russian industry are the following: Aganbegyan A., Ashkhotov V., Borodin A., Voronin V., Ganalov S., 
Deniskin V., Edelev D., Izryadnov O., Kerefov M., Kostenkov T., Novoselov S., Savvateev E., Tatuev A., Fomin P., Cherkesov E.

Thus, there arises a necessity for development of a proprietary technology of ranking evaluation of industrial enterprises strategic sustainability, based primarily on the business evaluation of executive personnel, analysis of internal environment of industrial enterprise, and defining the role and place of industrial enterprise in institutional environment.

\section{Results}

Let us study foreign experience of the USA and its instruments, used for sustainable development of industrial sector. Study of industrial sector is conducted by a strategic council which tracks the development of science and technologies. It should be noted that the issues of strategic development of industry and of formation of USA innovational system belong to the competence of (except the Council of Innovations) Administration for Technological Policy (ATP) and Trade Department (Vasilyev, 2009). These bodies are moderators for discussion of key issues as to industrial complex development. Consequently, it should be noted that foreign rivals, in order to ensure sustainable growth of industry, use the program "US Innovation Partnership Initiative" as a mechanism of strategic management of technological policy; this program is aimed at the mobilization of all resources of US industry and cooperation with business society which has a part in coordination and development of programs for development of innovational and investment environment.

All the above mentioned facilitates the rational choice of strategic course for sustainability of industrial sector. In our opinion, increase of social and economic effectiveness of industrial enterprises depends on state economic, regulatory, trade, and other policy, aimed at the stimulation of innovational activity and minimization of risks in technological development and commercialization of the results of research and solutions. Also, Administration for Technological Policy works in close cooperation with industrial companies.

In order to reach strategic effectiveness and sustainable economic growth (at year-end 2014, the USA ranks third in the global ranking according to the parameters (Figure 1)) it is necessary to define the strategic factors which motivate economically active population for development of new products. One of the key factors is a real cooperation of science, education, financing, state policy, and industry.

Viewing the ranking of countries as to sustainable development of industry for 2014, we shall reflect in the diagram the level of development of Russia among 148 countries (Figure 1) (2014).

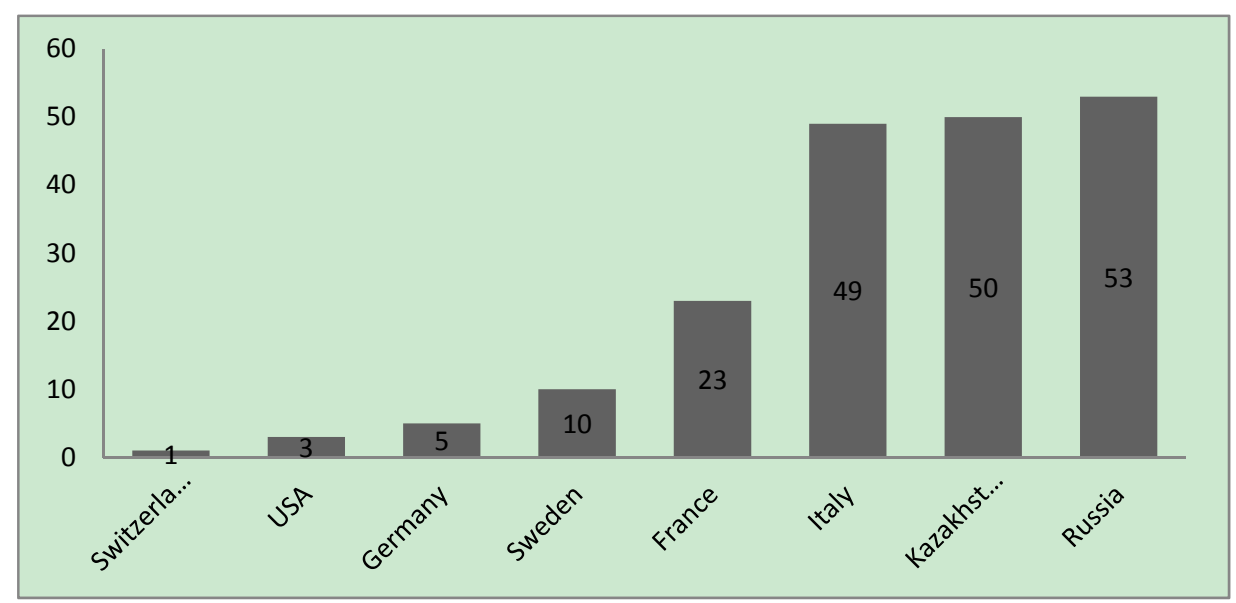

Figure 1. 2014 country rating, as to the level of sustainability of industry (compiled by the authors)

Figure 1 shows that Russia is a global leader as to natural resources, and ranks $53 \mathrm{~d}$ as to development of industry sustainability. In our opinion, the leading role in the ensuring sustainable development of Russia's economy belongs to innovations which facilitate the constant renewal of industry technological basis, acquisition and release of new production, and effective entry into the global markets.

In particular, the advantages of Japanese industrial companies are not only high labor efficiency, but also low direct expenses percentage wise to general expenses of companies-leaders as to the level of strategic sustainability of industrial enterprises of the USA and German-speaking countries. First of all, it's not just the labor efficiency, but the efficiency of management at all levels. 
It should be noted that creation of innovational economy is a strategic course of development of Russia in the $21^{\text {st }}$ century (Cherkesova, Dovlatyan, \& Ermakova, 2013).

At present, the issue of strategic sustainability of industrial complex is rather topical; primarily, it concerns not only the population's provision of food and manufactured goods, but the development rate of industrial sector.

Absence of common definition of strategic sustainability of industrial enterprise complicates the formation of adequate approach to its evaluation, which is rather necessary for analyzing the potential for its increase and which is dictated by the use of comparative approach.

Within the expansion of methodological and informational basis for managerial decision making, we offer a comparative analysis of peculiarities of various existing approaches for formation of the mechanism of strategic sustainability of industrial enterprises as a key feature of institutional environment (Table 1).

Analysis of the table allows considering the revealed scientific approaches. Thus, marketing approach to the evaluation of strategic sustainability constitutes in the determining parameters of market situation (revenue growth index), parameters of competitive situation (parameters characterizing the share of industrial enterprise in the market and relative market share) and parameters of the market situation change (they allow forecasting as to the future change of competitive advantages in the market). Within this approach, matrix methods are used (matrices ABL, BCG, GE/McKinsey). Evaluation with the use of matrix methods consists in the analysis of the matrix which is created according to the coordinate system.

Table 1. Comparative analysis of the approaches to evaluating the strategic sustainability of industrial enterprises (authors' development)

\begin{tabular}{|c|c|c|}
\hline Positions & Examples of rendering the strategic sustainability of enterprise & $\begin{array}{l}\text { Peculiarities of the } \\
\text { approach }\end{array}$ \\
\hline \multicolumn{3}{|c|}{ Marketing approach } \\
\hline Share of market & $\begin{array}{l}\text { Capability for creating, developing, and preserving competitive } \\
\text { advantages }\end{array}$ & Market sustainability \\
\hline \multicolumn{3}{|c|}{ Systemic approach } \\
\hline $\begin{array}{l}\text { Integrity } \\
\text { Hierarchy } \\
\text { Structuring }\end{array}$ & Based on the use of integrity and consistency potential & $\begin{array}{c}\text { Financial } \\
\text { sustainability }\end{array}$ \\
\hline \multicolumn{3}{|c|}{ Innovational approach } \\
\hline Innovation & $\begin{array}{c}\text { Capability for permanent implementation of innovations into } \\
\text { industrial and managerial activity }\end{array}$ & $\begin{array}{l}\text { Innovational } \\
\text { sustainability }\end{array}$ \\
\hline \multicolumn{3}{|c|}{ Complex approach } \\
\hline $\begin{array}{l}\text { Technologies level } \\
\text { control }\end{array}$ & Capability for modernization of technological process & $\begin{array}{l}\text { Technological } \\
\text { sustainability }\end{array}$ \\
\hline \multicolumn{3}{|c|}{ Competence-based approach } \\
\hline Labor potential & $\begin{array}{c}\text { Capability for keeping high level of competence and low level } \\
\text { of staff turnover }\end{array}$ & $\begin{array}{c}\text { Employee } \\
\text { sustainability }\end{array}$ \\
\hline
\end{tabular}

For evaluation of customer satisfaction, the methods of interview and statistical processing of the received data, as well as questionnaires, are used. These methods are peculiar for their labor intensity and duration of gathering and processing data, which, however, is compensated by the possibility of revealing the problems in ensuring the sustainability of industrial enterprise.

In modern theory of industrial complex management, the systemic approach is one of the basic ones, allowing logically finding a variety of equal technical solutions. The systemic approach, as a general methodological principle, is used in human activity and in various branches of science. Epistemological basis (epistemology is a branch of philosophy, studying methods and forms of scientific cognition) is the common theory of systems, the origins of which were created by the Australian scientist Karl Ludwig von Bertalanffy (Spivak, 2007). It covers 
the development of specialized methodology of research of the systems. The task of systemic approach is expressing principles and notions of systemic research at the level of a single general scientific methodology.

The systemic approach in management is based on the fact that any organization is a system consisting of parts, each of which possesses its own goals. At that, it is necessary to find and evaluate the cooperation of all its parts and combine them on the basis which will allow the organization to effectively realize its goals.

According to V. A. Spivak, it is advised to discern the main principles of the systemic approach: integrity, hierarchy of structure, structuring, and multiplicity.

In our opinion, the meaning of the systemic approach consists in managers being able to perform their specific activity, with a specific role and place in the system.

In order to find the strategic sustainability, various methods are used, most of which are based on the discovery of integral parameters of a specific type of production, depending on the ratio of parameter index to economic index (Novoselov, 2013). The stated indices are discovered by adding private indices for each of the evaluated parameters with regard to weighting coefficients. Sustainability parameters are discovered for each type of activity of industrial enterprise, and then a coefficient of the level of industrial enterprise is discovered, as a weighted average among the parameters for each type of activity, where the weights are productivity and rentability.

Innovational approach to evaluation of strategic sustainability of industrial enterprise is rather topical and possesses strategic and managerial nature. On the one hand, it grants the right to create innovations, on the other hand - to evaluate who's creating them. At corporate planning and forecasting, a special importance belongs to the innovational approach - it is an impulse to learning innovations and entry of the industrial enterprise on the sustainable path of development.

Let us consider the complex approach which studies the complex evaluation of the activity of industrial enterprise and determines not only current, but also potential level of sustainability as to the innovational potential. Evaluation of the current (real) and potential sustainability and their ratio within the integral parameter may vary depending on the method (Novoselova, 2012). The current sustainability may be determined, for example, on the basis of evaluation of strategic sustainability of industrial enterprise, and potential one - similar to the methods, based on the economic effectiveness.

Let's consider the whole institutional angle of the notion of "competence-based approach" as an assembly of interconnected personal, behavioral, and professional competencies, required for work, offering in competitive conditions the specific tools and principles for delimitation of competencies - regarding the sectors of the economy and spheres of society's activities and their reaching the "top-quality result".

\section{Discussion}

We substantiated that appearance in the business environment of the highest level of management of a new social and professional community will allow ensuring high quality of production of industrial enterprise as to the rivals, which is a key factor of winning leading positions in any field of activity. Issue of quality is very actual in Russia; low efficiency of activity is a risk factor of economic and social development of the country. Analyzing the experience of the developed countries, we made a conclusion: "competencies and labor quality are a symbol and tool of synthesis of all progressive changes in society and economy". The solution of this problem is impossible without qualified managers, the main task of which would be organization of effective work of management of all links (industrial and managerial processes).

A comparative analysis of main socio-economical features of approaches to evaluation of strategic sustainability of industrial enterprise, which we conducted, showed that competence-based approach is one of the most perspective and effective ones in the context of modern stage of development of national economy of Russia.

Within this stage of the research, let us assume that competence-based approach is an institutional tool for reaching strategic sustainability of an industrial enterprise.

The further chain of discourse will be built in the context of scientific reasoning of this research thesis.

Further, it is advisable to consider the key characteristics of industrial enterprises of Rostov Oblast and develop the strategic tools for increasing the strategic sustainability of industry, which will allow entering on a new level of Russia's industry. Let us consider the influence of the parameter of industrial production index at the full circle of industrial enterprises on the territories of Southern Federal District and evaluate the influence on the development of industry sustainability for 2013 (Figure 2). 


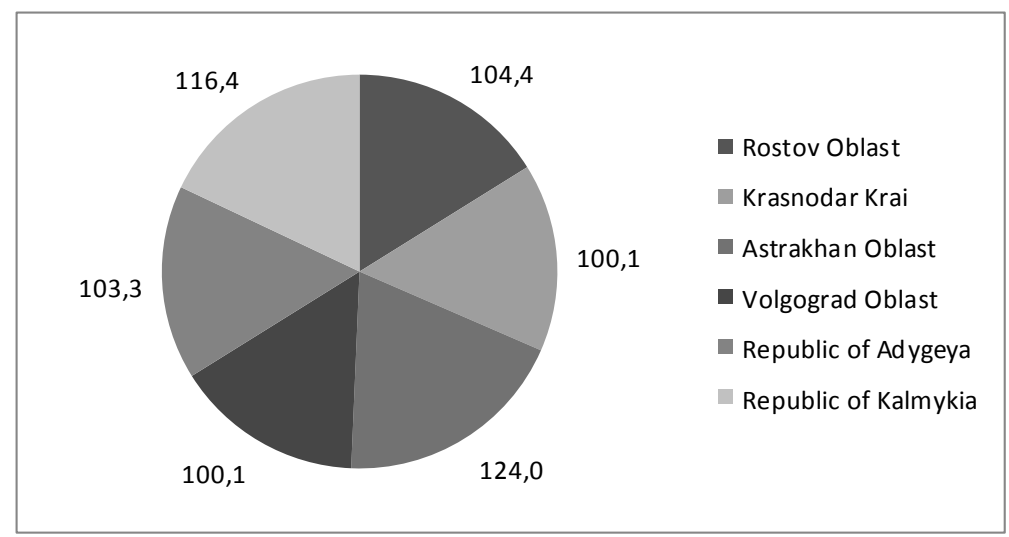

Figure 2. Analysis of industrial production index of industrial enterprises of Southern Federal District for 2013 (original development, compiled by the authors on the basis of the Rosstat reports for 2013)

Let us study the sectorial index of Rostov Oblast against the background of strategic sustainability of Don industry (Figure 3.)

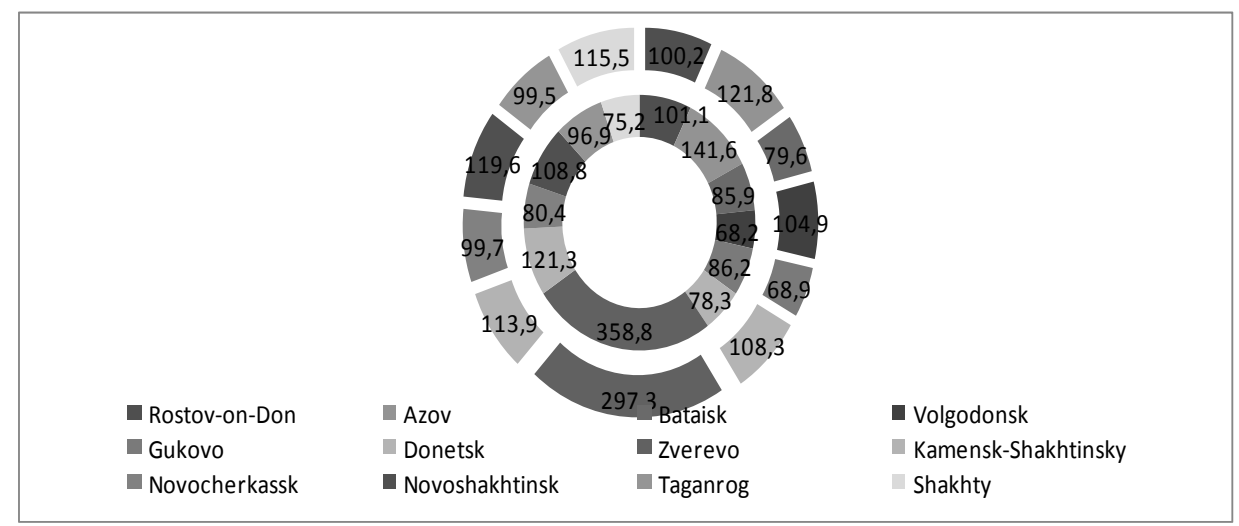

Figure 3. Index of industrial production of industrial enterprises in urban districts and municipal areas of Rostov

Oblast for 2013 (original development, compiled by the authors on the basis of the Rosstat reports for 2013)

This comparison vividly shows the high variation of parameters of a specific territory as to the quantity of industrial enterprises on a given territory.

The diagram shows sectorial parameters of average on establishment quantity of employees of Rostov Oblast industry for 2013 (Figure 4).

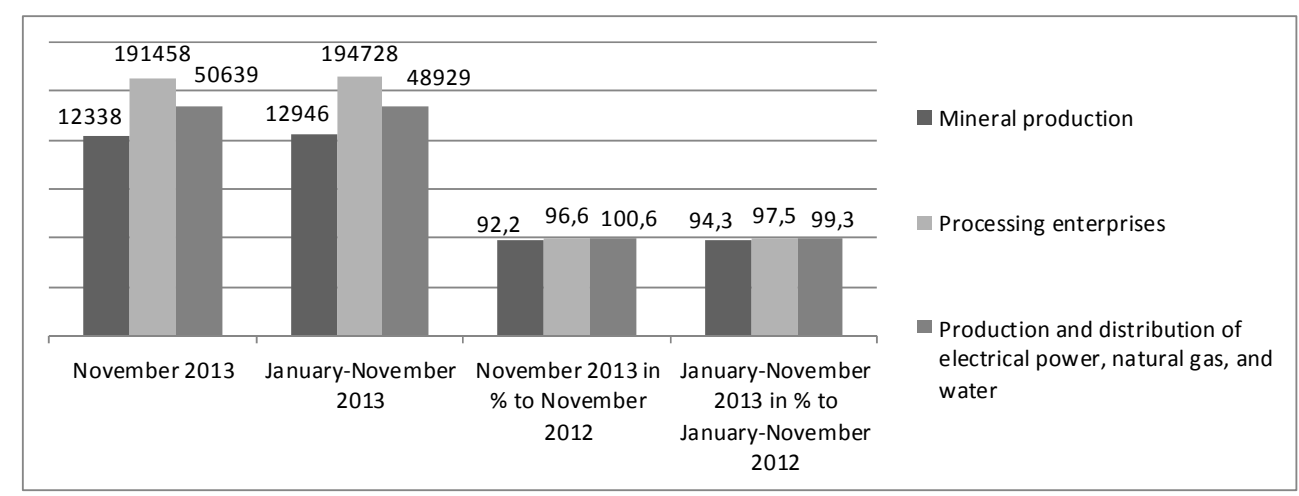

Figure 4. Sectorial dynamics of key features of industry for 2013, compared to 2012 (original development, compiled by the authors on the basis of the Rosstat reports for 2013) 
It should be noted that industrial enterprises undergo financial difficulties, which is caused by the reduction of prices for production. From the beginning of 2013, the industrial activity has almost stopped because of lack of operating capital, caused by the delay of payment for final products, delivered to the buyers.

In our opinion, it is advisable to analyze the outline of the knowledge economy, which includes the closely cooperating and interdependent systemic elements:

- informational and communicational technologies;

- human capital;

- business;

- institutional environment;

- national innovational policy.

Based on the above, let us consider the results of the poll which we conducted at the industrial enterprise Rostov Electrometallurgical Works LLC - a metallurgical plant of a new type which is producing top-quality production based on the technology of continuous steel casting and rolled steel. The plant is situated in Shakhty, Rostov Oblast; it occupies the area of 29 hectares, which is possible due to the basic engineering "CONCAST", enabling such compact placement. As the enterprise is unique for metallurgical sector of the country as to the level of automation of technological processes, and the designed capacity of the plant is 730,000 tons of steel and 530,000 tons of rolled steel per year, we chose this industrial enterprise for conducting the poll among the employees.

237 employees were interviewed anonymously. $35 \%$ of the employees are males, $65 \%$ - females. $65 \%$ of the employees are aged 29-39, 35\% - 40-49. Length employment is the following: 1-10 years - 84\%, 10-20 years $16 \% .8 \%$ of the respondents are managers, $92 \%$ - employees of medium and low levels.

The question "What feeling do you go to work with?" was answered by the respondents the following way (Figure 5).

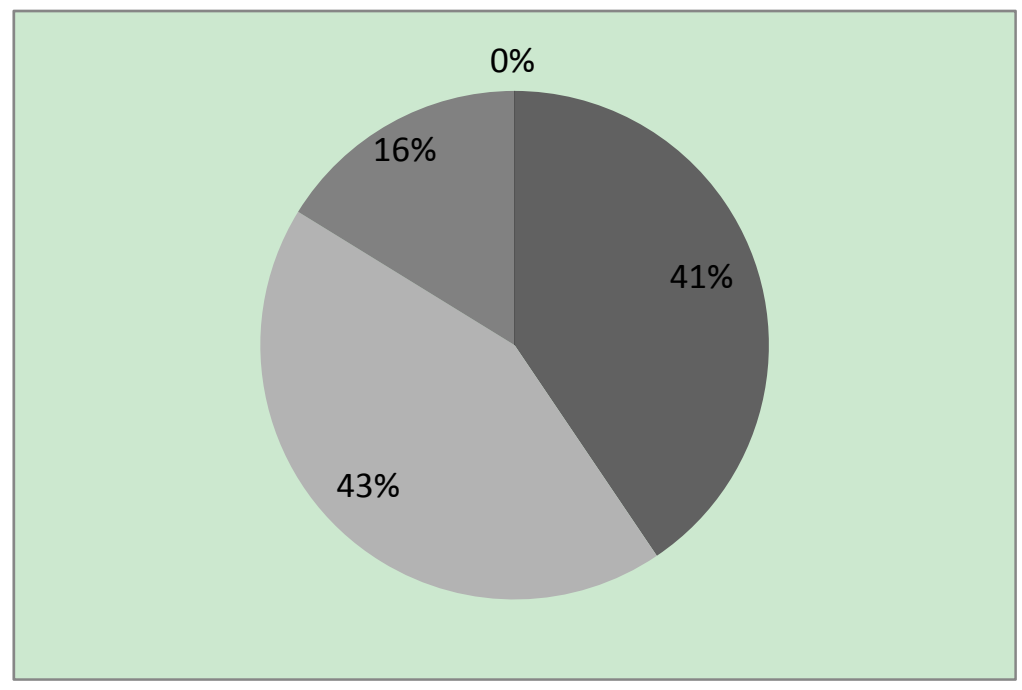

Figure 5. Strategic priorities for sustainable development of industrial enterprise (original development)

Figure 5 shows that $41 \%$ of the respondents go to work with pleasure; $43 \%$ have various feelings at various times, there's no specific feeling; $16 \%$ of the respondents couldn't give the answer. This proves that most of the respondents do not have motivation for labor, and, consequently, their contribution will not be a $100 \%$ one - and, consequently, the enterprise's goal will not be realized fully.

The question "To what extent are you satisfied with labor conditions at the workplace?" was answered the following way. $54 \%$ of the respondents - "fully satisfied", $32 \%$ - "partially satisfied", $6 \%$ - "partially not satisfied", $8 \%$ - could not give the answer (Figure 6). 


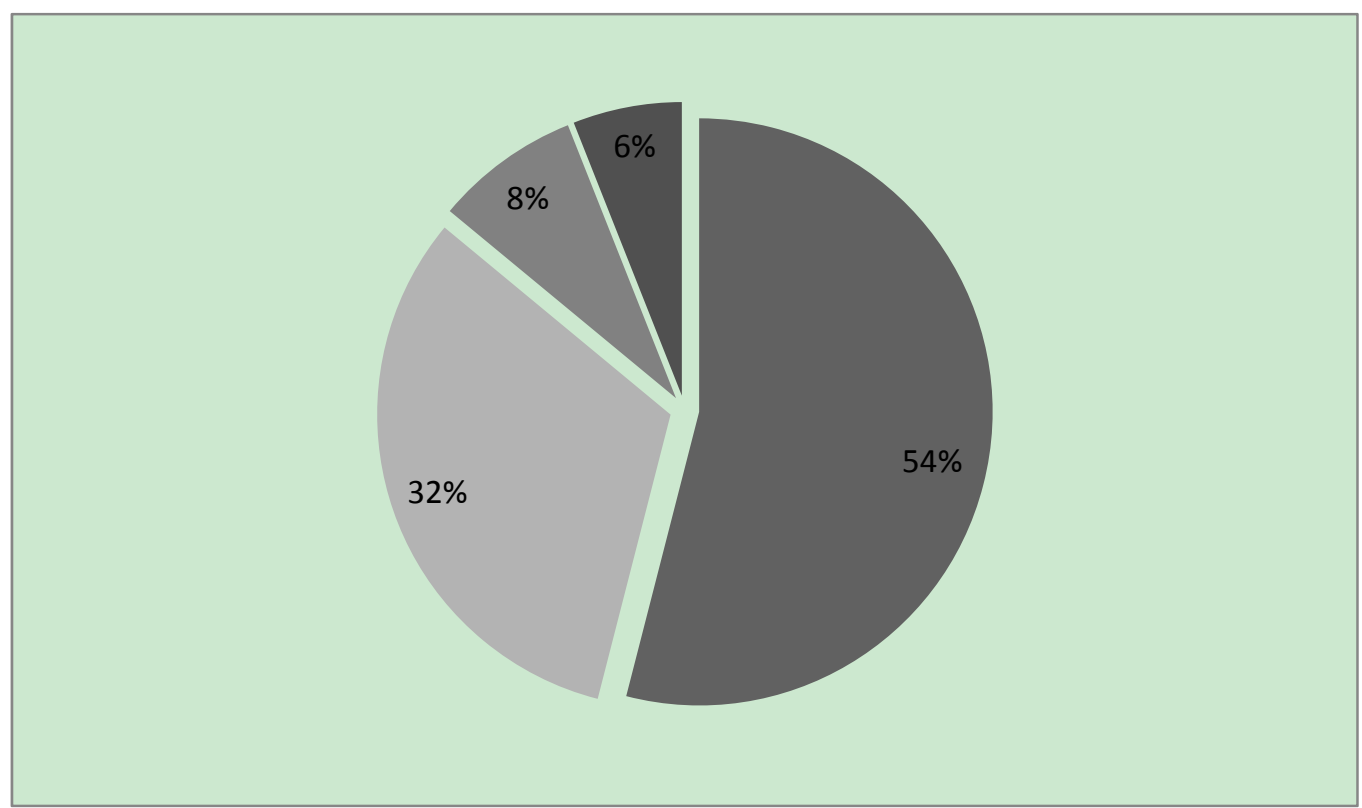

Figure 6. Key characteristics of institutional potential and use of tools for providing strategic sustainability of industrial enterprise (original development)

It should be noted that there are negative issues of the part of employees which are not interested in the work.

The question "What problems negatively influence the result of your work?":

$43 \%$ of the employees answered the following:

- rate of wages;

- much too heavy workload;

- frequent overtimes, excessive workload;

- $\quad 19 \%$ of the respondents answered that there was no career development (no promotion), or there were too many urgent errands (constant change of activity made it impossible to concentrate);

- $\quad 38 \%$ of the employees could not give the answer (Figure7).

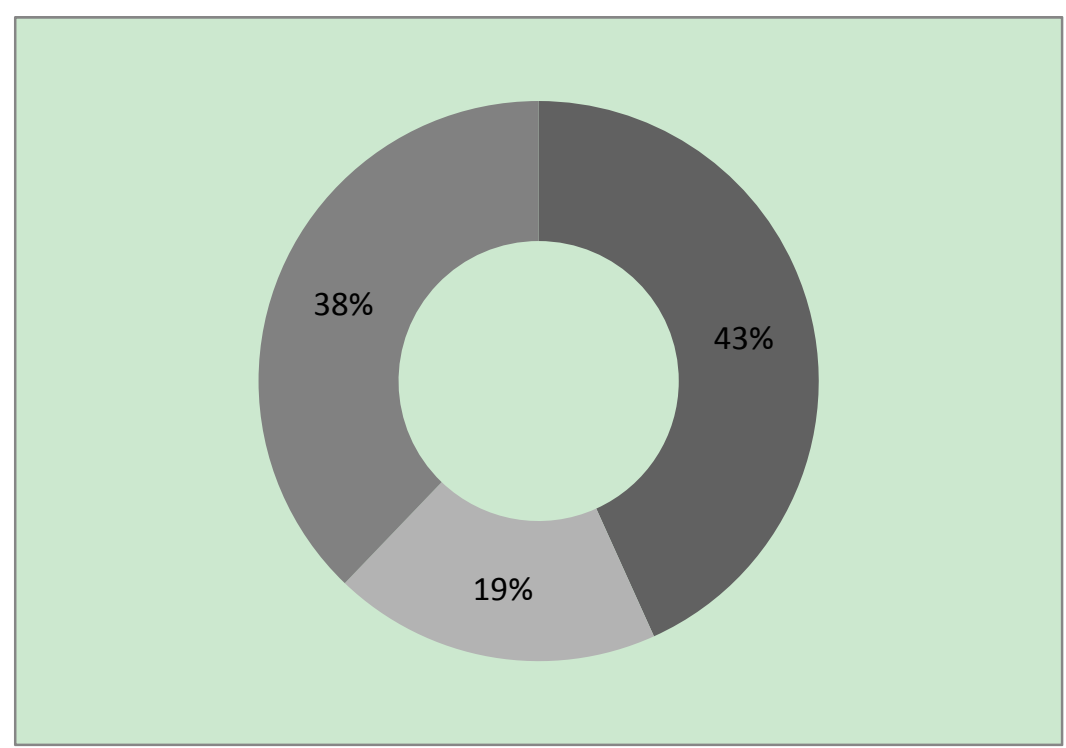

Figure 7. Dynamics of parameters which require institutional transformations in industrial sector (original development) 
Figure 7 shows that $100 \%$ of the employees have reasons which negatively influence the results of their labor that is reflected on the formation of strategic sustainability of industrial enterprise as a whole, for it is personnel that is a drive of any enterprise.

The request "Note the factors that, in your opinion, could make your work more attractive and increase the labor productivity":

$38 \%$ of the respondents chose and noted the following factors:

- chances for promotion;

- payment for labor according to the results (differentiated wages);

- flexible schedule;

$30 \%$ of the employees noted the chances for promotion and good relations with colleagues;

$32 \%$ of the respondents noted that they wanted recognition and approval from management for good results, and wanted to work without stress and pressure and do the work which would create conditions for studying, development, and perfecting their skills.

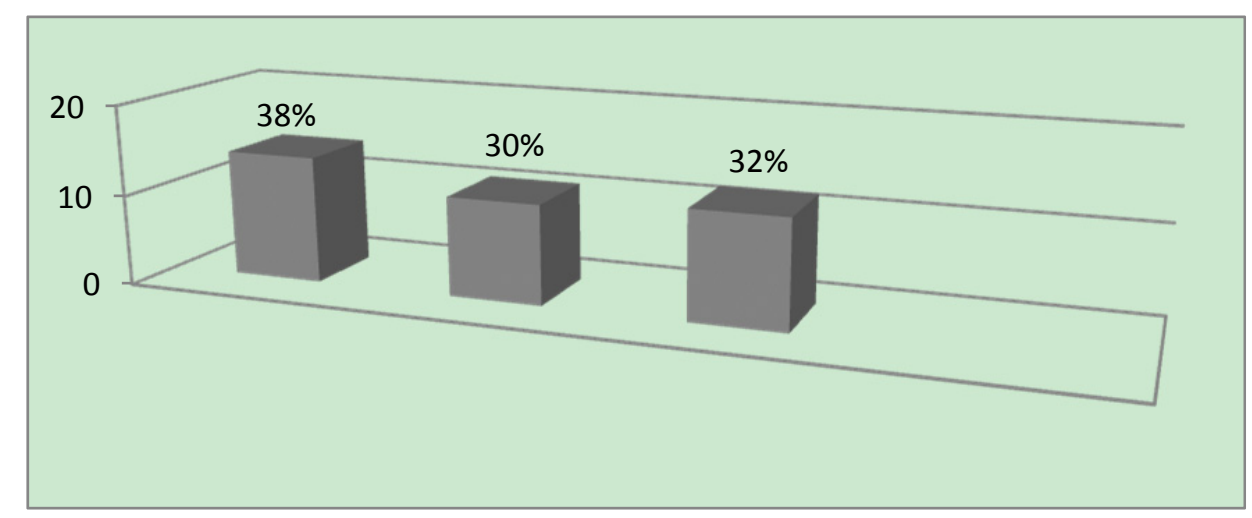

Figure 8. Key characteristics which influence strategic sustainability of industrial enterprise (original development)

Figure 8 shows that specialists are willing to work and develop in the professional sphere, but there are real risks which, in their opinion, slow these processes down.

The question "If you were to be encouraged, what would you prefer?": $4 \%$ of the respondents chose a bonus or other stimulating payment, $49 \%$ of the employees chose a promotion, $11 \%$ - awarding order, medal, honorary degree or other distinction, $16 \%$ - overseas travel.

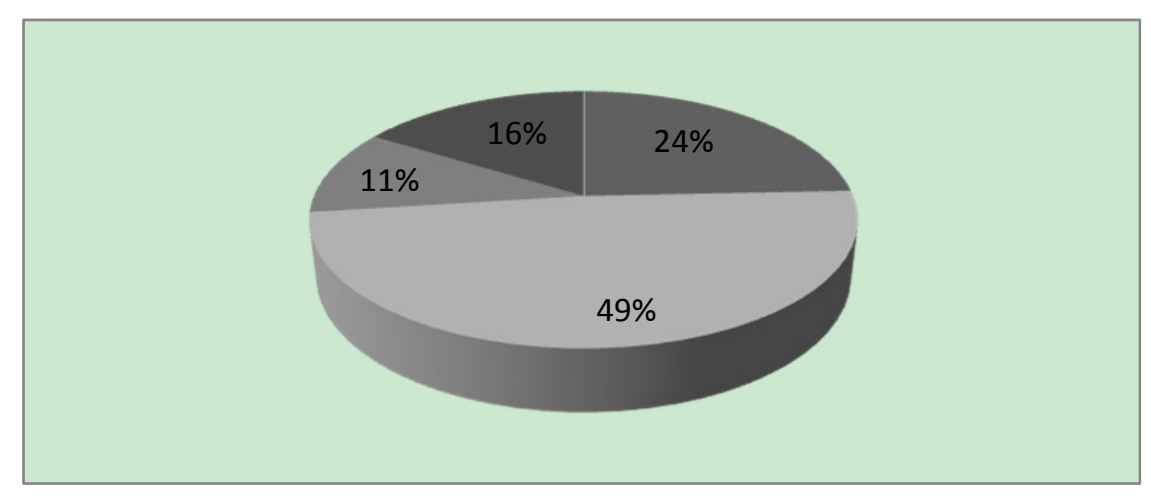

Figure 9. Priorities of strategic sustainability development of industrial enterprise (original development)

The question "Are you going to change the job in the nearest future?": $76 \%$ of the employees - "no", $8 \%$ - "yes, if there's a variant with larger salary", $16 \%$ could not give the answer. 
Summarizing the above, it is possible to conclude that the studied enterprises have potential for forming sustainable development which is, however, slowed down by absence of team spirit of the stuff, tense staff morale, absence of motivation, and progressing material dissatisfaction. It is recommended to find and form the conditions which would increase personnel labor efficiency and lead the studied industrial enterprise on the path of sustainable and strategic development.

\section{Conclusion}

Summarizing the above, we come to the following conclusion: economic difficulties at mega- and macro-level substantially influence the enterprise and its activity, reflecting on the socio-economic parameters (living standards of the population, transition of USSR's economy to market development, global financial crisis, and restructurisation of mining industry). It all was reflected on the activity of former mining territories. Despite all the difficulties, only the professionalism and competence of the managers can help to achieve a new level.

Developing a strategy for reforming economic system, it is necessary to prefer the courses of development which are adequate for institutional structure and mentality of population of a territorial and economic community, or an industrial enterprise.

In order to provide sustainable development of industrial enterprise in modern conditions, we suggest using a strategic instrument - competence-based approach which, in our opinion, is actual for development of innovational activity and is universal and applicable for all branches of national economy.

\section{References}

Alchian, A., \& Demsetz, H. (1972). Production, information costs and economic organization. American Economic Review, 62(5).

Bacon, R., \& Eltis, W. (1976). Britain's economic Problem: Too Few Producers. L., Mac Millan.

Cherkesova, E. Y., Dovlatyan, G. P., \& Ermakova, T. G. (2013). Human capital as a factor shaping the innovative personality. Applied and Fundamental Studies: Proceedings of the 2nd International Academic Conference, 2, 278-284.

Feldstein, M. (1974). Social security retirement and aggregate capital accumulation. Journal of Political Economy, 82. http://dx.doi.org/10.1086/260246

Hayek, F. (1986). The use of knowledge in society. The Nature of the firm: a reader (p. 189). Cambridge.

Kosorukov, O. (2012). Forecast of Separate Indicators for Socio-Economic Development of the Russian Federation up to 2020. World Applied Sciences Journal, 18(Special Issue of Economics), 5-10.

Misina, K., \& Musikhin, S. (2012). Mathematical Principles of the Dynamic Forecasting Model. World Applied Sciences Journal, 18(Special Issue of Economics), 1-4.

Mitrofanova, E., Konovalova, G., \& Belova, O. (2012). Personnel management: theory and practice. Competence-based approach to personnel management (p. 430). Prospekt, Moscow.

Norgaard, R. (1988). Sustainable Development: a Co-Evolutionary. Futures, 20(6), 613. http://dx.doi.org/10. 1016/0016-3287(88)90003-1

Novoselov, S. (2013). Role and place of local markets in providing sustainable development of the region. Modern fundamental and applied research, Special issue, 164-167.

Novoselova, N. (2012). Improving the efficiency of functioning and development of regional economies on the basis of existing resources and potential in view of possible influence of external and internal environment factors. Economics, statistics, and informatics. Bulletin of UMO, 3, 250-253.

Parker, D. (1993). Ownership, organizational changes and performance. In T. Clarke, \& C. Pitelis (Eds.), Political Economy of Privatization (p. 388).

Regions of Russia. Socio-economic parameters for 2012 (p. 300). (2013). Rosstat, Moscow.

Report on global competitiveness 2013-2014. (2014). E-source. Retrieved January 3, 2015, from http://www.weforum.org/reports/global-competitiveness-report-2013-2014

Rostov Oblast in numbers 2013 (p. 975). (2014). Rostovstat. Rostov-on-Don.

Russian statistical annals 2013 (p. 795). (2014). Rosstat, Moscow.

Spivak, V. (2007). Personnel management for managers: teaching guide (p. 624). Eksmo, Moscow.

Sukharev, O., \& Strizhakova, E. (2010). Efficiency of labor and industry: systemic task of management. 
Economics and enterprise, 8, 389-402.

Tanzharikova, A. Z. (2012). The Role of Higher Education System in Human Capital Formation. World Applied Sciences Journal, 18(Special Issue of Economics), 135-139.

Vasilyev, Y. (2009). Innovational management of industry development in USA, or ways of improving labor efficiency (p. 448). Ekonomika, Moscow.

World Economic Forum. (2013). The Global Competitiveness Report 2013-2014.

\section{Copyrights}

Copyright for this article is retained by the author(s), with first publication rights granted to the journal.

This is an open-access article distributed under the terms and conditions of the Creative Commons Attribution license (http://creativecommons.org/licenses/by/3.0/). 